\title{
RICARDO REIS: UM HOMEM E UM ANO
}

Demétrio Alves Paz. ${ }^{1}$

Resumo: O presente trabalho tem por objetivo analisar como se dá a relação entre literatura e história no romance $O$ ano da morte de Ricardo Reis, de José Saramago. Em nossa hipótese, a relação é estabelecida por meio da intertextualidade na obra. Para a análise, usamos três diálogos entre Ricardo Reis e Fernando Pessoa, mas que também se referem à Lídia, à Marcenda e ao contexto histórico presente no livro.

Palavras-Chave: Literatura. História. Intertextualidade. Saramago. Fernando Pessoa.

\section{RICARDO REIS: A MAN AND A YEAR}

Abstract: the purpose of this essay is to analyze the relation between Literature and History in the novel $O$ ano da morte de Ricardo Reis (The year of death of Ricardo Reis), by José Saramago. In your thesis, the relation is stablished by means of intertextuality in the book. To the analysis, we use three dialogues between Ricardo Reis and Fernando Pessoa, but also refered to Lídia, Marcenda and the historical context in the book.

Key-words: Literature. History. Intertextuality. Saramago. Fernando Pessoa.

\section{Dois homens e um ano}

Lisboa, 29 de dezembro de 1935. Desce do navio inglês Higland Brigade "Um homem grisalho, seco de carnes” (SARAMAGO, 2000, p. 15). Quem é esse homem? De onde ele vem? Qual a sua idade? Qual o seu nome? "Nome Ricardo Reis, idade quarenta e oito anos, natural do Porto, estado civil solteiro, profissão médico, última residência Rio de Janeiro, Brasil”. (SARAMAGO, 2000, p. 21). Qual é o seu passado? De acordo com Fernando Pessoa, em sua carta sobre a gênese dos heterônimos a Adolfo Casais Monteiro,

Ricardo Reis nasceu em 1887 (não me lembro do dia e mês, mas tenho-os algures), no Porto, é médico e está presentemente no Brasil. (...) educado num colégio de Jesuítas é, como disse, médico, vive no Brasil desde 1919, pois se expatriou espontaneamente por ser monárquico. É um latinista por educação alheia, e um semi-helenista por educação própria. (PESSOA, 1975, p. 175)

\footnotetext{
${ }^{1}$ Professor Adjunto 4 de Teoria Literária e Literaturas de Língua Portuguesa na Universidade Federal da Fronteira Sul (UFFS) Campus Cerro Largo - RS.
} 


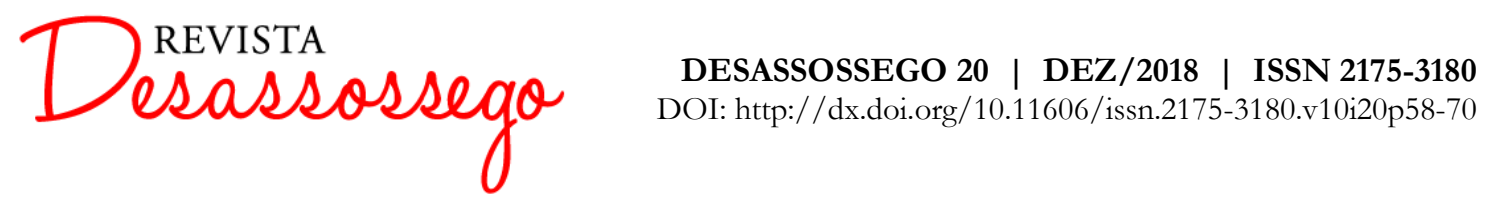

Entretanto, isso deve ser um engano, pois Ricardo Reis morreu em 30 de novembro de 1935, em Lisboa, junto com o seu criador: Fernando Pessoa. Se isso realmente aconteceu, esqueceram de avisar José Saramago. Para o Nobel de 1998, tanto Ricardo Reis quanto Álvaro de Campos não morreram com o seu inventor. Os dois estão vivos, e foi Álvaro que, antes de partir para a Escócia, comunicou a Ricardo a morte de Fernando, fazendo-o retornar a Portugal.

Dessa maneira inicia o romance de José Saramago, $O$ ano da morte de Ricardo Reis, publicado em 1984. Quarto romance escrito pelo ex-morador de Lanzarote, caso não seja considerado Terra do pecado, de 1947. O português José Saramago nasceu em novembro de 1922, na província do Ribatejo. Teve apenas ensino liceal e técnico. Exerceu diferentes profissões: serralheiro mecânico, desenhista, editor, tradutor, jornalista, crítico literário, entre outras. Marxista, membro do Partido Comunista, contista, romancista, dramaturgo, poeta, cronista e Prêmio Nobel de Literatura em 1988, Saramago preocupou-se com os portugueses e sua história. Contudo, prefere reescrever a história de Portugal, transformando-a em história dos portugueses. Baltasar e Blimunda, em Memorial do convento; Raimundo Silva e Maria Sara, em História do cerco de Lisboa; Ricardo Reis e Lídia, em O ano da morte de Ricardo Reis, todos esses portugueses têm suas histórias contadas por Saramago.

Em $O$ ano da morte de Ricardo Reis, a apropriação dos fatos históricos, notícias do cotidiano de Lisboa por meio de jornais, poemas de Fernando Pessoa, filmes, peças de teatro, romances e textos de outros grandes escritores dá-se por meio de intertextos. Visto que um texto "É absorção e replica a outro texto (ou vários outros)" (CARVALAHAL, 1992, p. 50) e que a intertextualidade, segundo Laurent Jenny,

Designa não uma soma confusa e misteriosa de influências, mas o trabalho de transformação e assimilação de vários textos, operado por um texto centralizador, que detém o comando de sentido. (APUD CARVALAHAL, 1992, p. 51)

Desse modo, deve-se pensar por que Saramago incorporou todos esses textos em seu romance e qual o novo sentido que lhes é atribuído. O intertexto de Saramago estabelece um diálogo com as idéias da História Nova, da qual traduziu diversas obras, por basear-se "Numa 


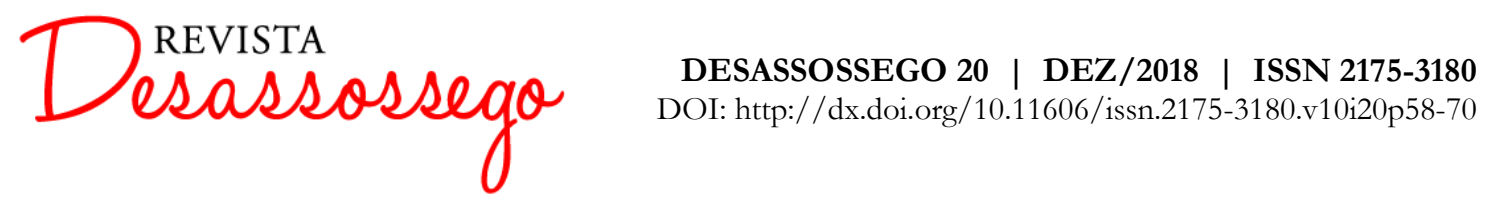

multiplicidade de documentos: escritos de todos os tipos” (LE GOFF, 2001, P. 28). Nesses escritos estão incluídos os já mencionados jornais, livros, filmes, além de utilizar-se também da literatura, especialmente a portuguesa, como fonte ficcional.

Ao escrever o que teria acontecido com o heterônimo de Fernando Pessoa, Ricardo Reis, Saramago o traz de volta para Portugal, ou melhor, Lisboa e viverá ali oito meses do ano de 1936, um ano crucial para a história contemporânea. Nesse ano, os totalitarismos se consolidavam na Europa: Hitler, Mussolini, Salazar. Franco tentava alcançar o poder na Espanha; os nazistas armavam a Renânia; os fascistas atacavam a Etiópia; o perigo vermelho (comunismo) preocupava a Europa. A Alemanha crescia econômica, militar e ideologicamente. Ela também se unia à Itália e seus projetos expansionistas. França e Inglaterra pouco faziam contra a Itália e Alemanha, pois tinham uma política pacifista para evitar uma nova guerra.

Em Portugal, o Estado Novo de Salazar tinha como orientações principais: um corporativismo, no qual o estado tinha um controle total; o apoio da Igreja, pois o regime era conservador, baseado em princípios tradicionais de Deus, Pátria, Família, Autoridade; uma censura voltada para a moral e os bons costumes; polícia política, a PVDE, que perseguia aqueles que discordavam do regime; isolacionismo, o qual manteve Portugal neutro da $2^{\mathrm{a}}$ guerra mundial; criação de milícias, a saber, Legião Portuguesa, Mocidade Portuguesa, entre outras (SARAIVA, 1985).

Pode-se dizer que o objetivo de Saramago, ao apropriar-se de fatos reais e comprováveis, é contextualizar suas personagens num mundo "real" e fazê-las discutir e viver o que está acontecendo no ano de 1936. O principal meio de ver esse mundo é o jornal. Por que o jornal? "Por falar do mundo geral, servia de barreira contra este ouro mundo próximo e sitiante" (SARAMAGO, 2000, p. 52). Além disso, o jornal era o principal veículo de informação da época. É por meio do jornal que Ricardo Reis saberá que Jorge V da Inglaterra morreu e que Eduardo VIII será o novo rei; que as divergências entre Calvo Sotelo e Gil Robles podem prejudicar a direita na Espanha; que a Anchluss é repudiada pelos Austríacos; que Luis Carlos Prestes é preso no Brasil; que Franco começa um levante contra o governo de esquerda de Manuel Azaña, dando início à guerra civil espanhola, entre outras notícias.

Como Saramago não está em 1936 (está escrevendo em outra época, 1984), já conhece os fatos e sabe o que acontecerá depois, o seu narrador assume uma postura irônica frente aos 


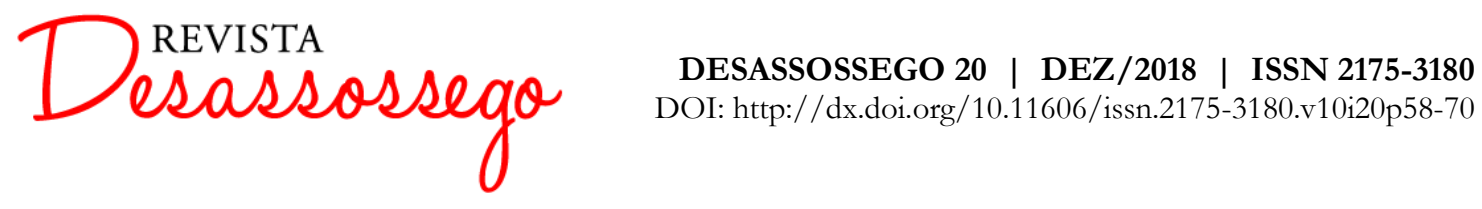

eventos passados. Desse modo, pode-se dividir o título do romance em duas partes. Primeira, o ano da morte, 1936, apresentado anteriormente. Segunda, Ricardo Reis, o heterônimo de Fernando Pessoa. Dos três heterônimos, ele é o mais clássico, afinal, Fernando Pessoa pôs nele a sua disciplina mental. Poeta de odes inspiradas em Horácio, Ricardo Reis "É um espectador do espetáculo do mundo, sábio se isso for sabedoria, alheio e indiferente por educação e atitude" (SARAMAGO, 2000, p. 90). O narrador aproveita-se da ode 13 de Ricardo Reis (PESSOA, 2000, p. 42-43), fazendo uma paródia cheia de ironia, característica estilística de Saramago, para demonstrar o descompromisso social de seu personagem com a sua época. Ricardo Reis, com seu ideal clássico de contemplacionismo, tal como na ode 34 em que "Os deuses são deuses porque não pensam” (PESSOA, 2000, p. 69), de certa forma não pensa, isto é, não quer pensar em seu país e no mundo. Afinal, "Os jornais, que tudo dizem menos o que quer”, (SARAMAGO, 2000, p. 203) eles dizem como está o mundo e Ricardo não quer saber disso.

Como antes dito, ao inserir Ricardo Reis num contexto histórico real tem-se a mimesis, que dá verossimilhança à história. O heterônimo de Fernando Pessoa move-se numa Lisboa possível de 1936. Se as personagens Lídia, Marcenda, Dr.Sampaio, Victor, Daniel não existiram realmente, não importa, pois existem no romance. Pondo vida no heterônimo de Pessoa, Saramago faz com que o contemplacionismo e o idealismo de Reis se transformem em ação, visto que agora ele é um "ser humano", que vive como outro qualquer. Sua atitude estética e estilística na arte não pode ser a mesma perante a vida. Por isso, ao chegar a Lisboa, tem a impressão de que a cidade não mudou tanto, como lhe foi dito pelo taxista. Hospeda-se no hotel Bragança, onde passará três meses. Nesse local, conhecerá Salvador, o gerente do hotel, Pimenta, carregador e garçom, Lídia, camareira e cozinheira, assim como futura amante, e Marcenda, futura paixão.

Ao organizar as suas roupas, papéis e livros, percebe que havia trazido um livro da biblioteca do Highland Brigade intitulado The god of the labyrinth, de Herbert Quain. Na verdade, esse é o título de um dos livros desse autor inventado por Jorge Luis Borges em seu conto Exame da obra de Herbert Quain (BORGES, 2000, p. 511-515). Durante os oito meses que passa em Lisboa, a personagem principal não conseguirá acabar de ler essa obra. Por que Ricardo escolheu este romance? O narrador responde: 


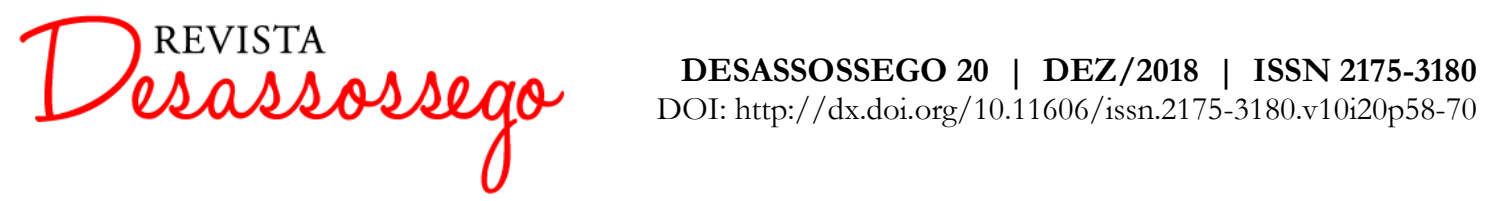

O tédio da viagem e a sugestão do título o tinham atraído, um labirinto com um deus, que deus seria, que labirinto era, que deus labiríntico, e afinal saíralhe um simples romance policial, uma vulgar história de assassínio e investigação, o criminoso, a vítima, se pelo contrário não preexiste a vítima ao criminoso, e finalmente o detective, todos três cúmplices da morte. (SARAMAGO, 2000, p. 23).

Saramago aproveitou-se de duas lacunas. A primeira deixada por Borges em seu conto, não contando toda a história, mas apenas resumindo o enredo e citando uma frase: "Todos acreditaram que o encontro dos jogadores de xadrez fora casual.” (BORGES, 2000, p. 512). Esta frase pode ter sugerido a Saramago a relação com a ode Os jogadores de xadrez̧ de Ricardo Reis, portanto o interesse dele estaria justificado. A segunda, por Fernando Pessoa ao dizer, na carta sobre a gênese dos heterônimos, que gostaria de iniciar suas publicações com um romance policial, mas que não teve tempo de acabá-lo. Também daí viria o gosto de Ricardo Reis pelo gênero.

Tem-se, então, a intertextualidade com os textos de Ricardo Reis e Borges, pois deles surge um novo texto, com um novo sentido. De certa forma, Saramago vai além do que Borges (2000, p. 490-498) realizou em Pierre Menard, autor do Quixote, visto que Saramago preencheu a lacuna deixada por Borges, acrescentando idéias que não estavam no texto original.

Labiríntica, também, será a Lisboa de 1936, pois Ricardo Reis e, principalmente, Fernando Pessoa, que vai perdendo a memória, seguidamente sentir-se-ão perdidos como em um labirinto, que os conduz ao mesmo lugar: a estátua de Camões. Conforme o narrador, "Todos os caminhos portugueses vão dar a Camões, cada vez mudado consoante os olhos que o vêem.” (SARAMAGO, 2000, p. 180-181). Isso demonstra quanto o escritor renascentista serve de paradigma para a produção literária em Portugal, desde o século XVI, e como as gerações seguintes interpretaram-no e usaram-no de modelo. Fernando Pessoa e Camões são considerados os dois maiores poetas da língua portuguesa, porém na Mensagem não há um só poema dedicado a Camões. No romance, Fernando Pessoa pensa o porquê dessa falta, e o próprio Camões responde-lhe que foi inveja.

Ainda arrumando seus papéis, Ricardo Reis encontra versos seus, em especial, "Mestre são plácidas todas as horas que nós perdemos" (SARAMAGO, 2000, p. 23), e "Vivem em nós 
inúmeros, se penso ou sinto, ignoro quem é que pensa ou sente, sou somente o lugar onde se pensa e sente.” (SARAMAGO, 2000, p. 24). Saramago inverte o último verso de Ricardo Reis, pois o original está assim “onde se sente ou pensa." (PESSOA, 2000, p. 139). Ao trocar a ordem dos verbos sentir e pensar, assim como a conjunção alternativa ou pela aditiva e, Saramago muda o sentido do verso e faz com que Ricardo Reis reflita sobre a sua condição, fazendo-se a pergunta existencial básica: quem sou eu? Não chegando à conclusão alguma. Após refletir sobre sua condição, guarda seus poemas.

Para informar-se sobre a terra natal, Ricardo lê os jornais. Neles, ele encontra diferentes notícias sobre a morte de Fernando Pessoa. Contudo, uma chama mais a sua atenção, pois diz que Fernando Pessoa era, na poesia, outros, entre eles Ricardo Reis. O narrador intromete-se e explica:

Pronto, já cá faltava o erro, a desatenção, o escrever por ouvir dizer, quando muito bem sabemos, nós, que Ricardo Reis é sim este homem que está lendo o jornal com seus próprios olhos abertos e vivos, médico, de quarenta e oito anos de idade, mais um que a idade de Fernando Pessoa quando the fecharam os olhos, esses sim, mortos. (SARAMAGO, 2000, p. 36).

O nós do texto estabelece um diálogo com os leitores e novamente se tem a verossimilhança, pois atesta a veracidade do relato, já que Ricardo Reis está vivo e até pode ser comprovada essa autenticidade:

Se ainda aí houver quem duvide, esse vá ao Hotel Bragança e fale com o senhor Salvador, que é o gerente, pergunte se não está lá hospedado um senhor chamado Ricardo Reis, médico, que veio do Brasil. (SARAMAGO, 2000, p. 36).

Nesse mesmo dia, Ricardo Reis resolve visitar Fernando Pessoa no cemitério dos Prazeres, não se sente bem e resolve ir embora por causa da chuva. No hotel, esqueceu a janela aberta e pede que alguém vá secar o seu quarto. Lídia é designada para a tarefa. Ao descobrir o nome dela, pensa na Lídia de suas odes.

Entretanto, a primeira Lídia é diferente da segunda, é uma mulher do povo, que acredita no irmão e na família. Trabalhadora, dedicada, caprichosa e submissa, mas que aprendeu com a vida e com a sabedoria popular, de que Saramago tanto gosta. Após ter tocado 


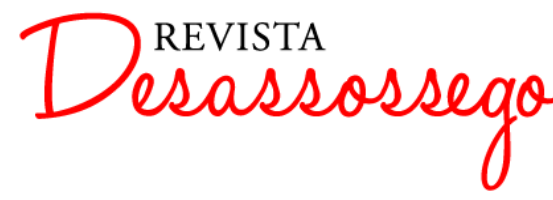

DESASSOSSEGO 20 | DEZ/2018 | ISSN 2175-3180

DOI: http://dx.doi.org/10.11606/issn.2175-3180.v10i20p58-70

em Lídia, Ricardo sente despertar em si o desejo por ela. Três dias depois, diz a ela que a acha bonita. Por isso, lembra-se dos versos do poema em linha reta, de Álvaro de campos: "Eu, que tenho sido cómico às criadas de hotel”. (SARAMAGO, 2000, p. 98). Na mesma noite, Lídia vem ao seu quarto. O próprio Ricardo Reis tem consciência das diferenças entre as duas Lídias, pois as suas musas "não são mulheres verdadeiras, mas abstrações líricas", afinal "às musas não se pede que falem, apenas que sejam”. (SARAMAGO, 2000, p. 297). Ele reconhecerá

O que são coincidências, eu há tantos anos a escrever poesias para uma Lídia desconhecida, incorpórea, e vim encontrar num hotel uma criada com esse nome, só o nome, que no resto não se parecem em nada. (SARAMAGO, 2000, p. 297-298).

E como o narrador diz:

Ela por acaso Lídia, mas outra, ainda assim afortunada, porque a dos versos nunca soube que gemidos e suspiros estes são, não fez mais que estar sentada à beira dos regatos, a ouvir dizer, Sofro, Lídia, do medo do destino. (SARAMAGO, 2000, p. 108).

No hotel, Ricardo Reis repara em Marcenda e descobre mais sobre ela e o pai com Salvador. Eles ficam três dias por mês no hotel para o tratamento dela, pois vêm da cidade do Porto. Ao descobrir que ela irá ao teatro com o pai assistir à peça Tá Mar, de Alfredo Cortez, resolve ir também. No teatro, apresenta-se ao Dr. Sampaio, pai de Marcenda, e depois é apresentado a Marcenda. A partir daí, tornaram-se amigos.

Marcenda, paralisada da mão esquerda, após a morte de sua mãe, não tem esperança de sua cura. Talvez ela seja um emblema da esquerda nos anos 30, que foi completamente anulada na Europa pelos regimes totalitários: fascismo, nazismo, franquismo e salazarismo. A democracia e o comunismo, principalmente esse último, eram uma ameaça ao poder centralizador de Hitler, Mussolini, Franco e Salazar. Marcenda faz o que o pai, Dr. Sampaio, manda e contenta-se com a sua posição. Ela aparece na Ode XVIII de Ricardo Reis, que assim inicia: "Saudoso já deste verão que vejo." (PESSSOA, 2000, p. 24). Seu nome vem de um gerúndio, forma nominal do verbo, por isso Saramago o usou como nome próprio, porém acrescentando-lhe a carga semântica do verbo na personagem: marcer, murchar. A primeira 


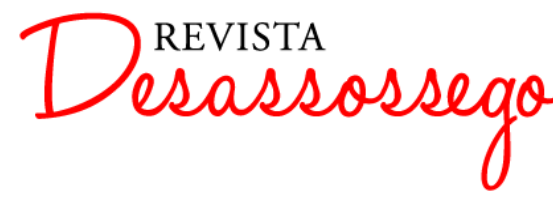

DESASSOSSEGO 20 | DEZ/2018 | ISSN 2175-3180

DOI: http://dx.doi.org/10.11606/issn.2175-3180.v10i20p58-70

vez que Ricardo Reis vê Marcenda, ele demora a perceber que a mão esquerda dela é paralisada, "Mãozinha duas vezes esquerda, por estar desse lado e ser canhota, inábil, inerte, mão morta." (SARAMAGO, 2000, p. 26).

No último dia de 1935, ao caminhar pela cidade, Ricardo Reis pára em frente à estátua de Eça de Queirós. O narrador intromete-se e modifica a frase "Sobre a nudez forte da verdade o manto diáfano da fantasia" de Eça para "Sobre a nudez forte da fantasia o manto diáfano da verdade", visto que "Este dito, sim, dá muito mais que pensar." (SARAMAGO, 2000, p. 62). Saramago parodia, mais uma vez, uma frase de um ícone da literatura portuguesa, e, mais do que isso, de uma forma de narrar tida como modelar para muitos escritores e críticos. É a subversão do próprio gênero romance, que teve seu ápice no século XIX com o Realismo, do qual Eça foi um dos principais expoentes, junto com Machado de Assis e Gustave Flaubert, por exemplo. Essa forma de narrar não tem mais espaço nem sentido na contemporaneidade, mas pode ser revitalizada por meio da paródia, como Saramago fez.

Um dia após visitar o túmulo de Fernando Pessoa, na primeira noite de 1936, Ricardo Reis recebe a visita de seu criador. O Fernando Pessoa saramagueano é extremamente irônico, assemelhando-se mais a Álvaro de Campos e ao próprio Saramago do que ao "poeta extraordinário da Mensagem, poema de exaltação nacionalista, dos mais belos que se têm escrito" (SARAMAGO, 2000, p. 35-36). Ao longo do romance eles encontram-se onze vezes. ${ }^{2}$ Para a análise, usarei apenas três diálogos.

\section{Criador X Criatura em três diálogos}

No primeiro encontro, Fernando informa a Ricardo que, após a morte física, tem oito meses de vida na memória das pessoas e pode andar por toda cidade livremente, só sendo visto por quem ele quiser. Além dessas vantagens, os mortos sabem de tudo. Ricardo diz-lhe que recebeu um telegrama de Álvaro de Campos comunicando a morte de Pessoa. Reis também lhe diz que voltou porque no Brasil ocorreu uma revolução em novembro. Aproveitando-se do que o outro havia falado, Pessoa comenta:

\footnotetext{
${ }^{2}$ Respectivamente nas páginas 79-82, 93-94, 117-119, 147-148, 154-155, 181-183, 225-228, 273-283, 329334, 358-362, 414-415.
} 
Você, Reis, tem sina de andar a fugir das revoluções, em mil novecentos e dezanove foi para o Brasil por causa de uma que falhou, agora foge do Brasil por causa de outra que, provavelmente, falhou também. (SARAMAGO, 2000, p. 81).

Saramago aproveitou-se que Fernando Pessoa havia dito, na carta sobre a gênese dos heterônimos, que Ricardo Reis estava no Brasil desde 1919. Aproveitou-se também de dois fatos históricos para essas fugas. O primeiro é a tentativa de colocar a monarquia no poder novamente. Em dezembro de 1918, o presidente Sidónio Pais é assassinado. Em janeiro de 1919, a monarquia é proclamada em Lisboa e Porto, mas por pouco tempo. Os Republicanos conseguem dominar a revolução e colocar um novo presidente no poder: António José de Almeida. O segundo, a intentona comunista ocorrida em vinte e sete de novembro de 1935, no Rio de Janeiro, próxima a morte de Fernando Pessoa. Essas duas revoluções atestam as fugas do Reis de Saramago.

Fernando Pessoa olha-se num espelho e não se enxerga, ao contrário de Ricardo Reis que se olhara antes e vira "Um dos inúmeros que é" (SARAMAGO, 2000, p. 31). Ricardo admite também ter voltado a Portugal para ocupar o lugar de Pessoa. Do mesmo modo, ele salientará que "Nenhum de nós é verdadeiramente vivo nem verdadeiramente morto" (SARAMAGO, 2000, p. 82), significando esse nós, Ricardo e Pessoa. Aqui está uma questão importante para o entendimento da obra: enquanto heterônimo de Fernando Pessoa, Ricardo Reis não tem vida própria como o seu criador. Contudo, como personagem ficcional ele está mais vivo do que o seu criador, morto em trinta de novembro de mil novecentos e trinta e cinco. Por isso que Luís de Sousa Rebelo, em sua resenha a O ano da morte de Ricardo Reis, diz:

Escolher um desses heterônimos e dar-lhe um estatuto civil, enredá-lo nas malhas de um quotidiano bem datado e marcado com a escória que caracteriza todos os cotidianos, sobretudo quando a personagem eleita é poeta e artista, envolta nas brumas de uma ambiguidade que invariavelmente se furta aos compromissos da enunciação, é tarefa delicada e susceptível de criar certas reservas acerca da validade estética de um tal projecto. (REBELO, 1985, p. 144) 


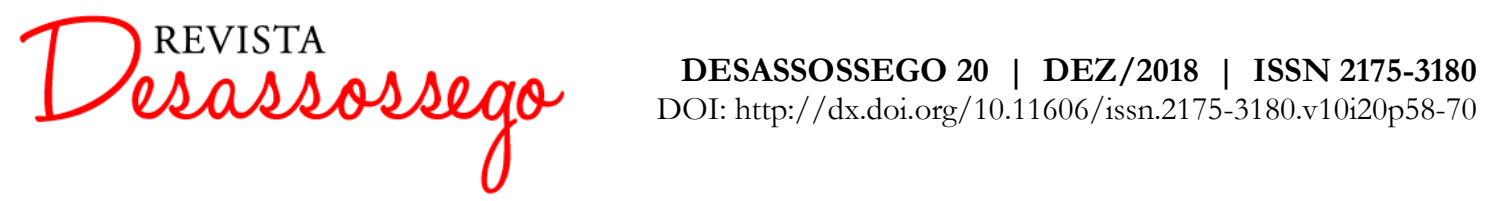

Sabe-se que Saramago conseguiu vencer as dificuldades impostas pelo seu projeto e criou um Ricardo Reis a altura do verdadeiro.

No terceiro encontro, Ricardo está deitado e Fernando aparece em seu quarto. Como Reis esperava por Lídia, pensou que ela poderia entrar a qualquer momento e Pessoa continuaria ali, já que ele não seria visto por ela e assistiria “às intimidades carnais e sentimentais" de Reis (SARAMAGO, 2000, p. 117-118). O narrador continua e compara a posição de observador de Fernando com a de Deus, pois "não seria nada impossível, Deus, que é Deus, costuma fazê-lo, nem o pode evitar, se está em toda a parte, mas a este já nos habituamos." (SARAMAGO, 2000, p. 118). Aproveitando-se do fato de ser dito que Deus é onipresente, ele ironiza a sua posição e ao fato das pessoas crerem nisso. Reis diz a Pessoa que está esperando uma visita. Fernando lhe responde: "você não perde tempo, ainda não há três semanas que chegou, e já recebe visitas galantes, presumo que serão galantes" (SARAMAGO, 2000, p. 118). Reis responde-lhe que ela é uma criada do hotel, deixando claro a sua posição em relação à Lídia. Mais uma vez, Pessoa é irônico:

Meu caro Reis, você, um esteta, íntimo de todas as deusas do Olimpo, a abrir os lençóis da sua cama a uma criada de hotel, a uma serviçal, eu que me habituei a ouvi-lo falar a toda hora, com admirável constância das suas Lídias, Neeras e Cloes, e agora sai-me cativo duma criada, que grande decepção. (SARAMAGO, 2000, p. 118)

Reis tenta defender-se e diz que o nome dela é Lídia, mas Pessoa continua a troça "Ah, ah, afinal a tão falada justiça poética sempre existe, tem graça até a situação, tanto você chamou por Lídia, que Lídia veio" Ricardo, outra vez, defende-se "veio o nome de Lídia, não veio a mulher". Pessoa continua "não seja ingrato, você sabe lá que mulher seria a Lídia das suas odes, admitindo que exista tal fenômeno, essa impossível soma de passividade, silêncio sábio e puro espírito". Ele ainda duvida de que exista o poeta que escreveu as odes de Reis. Pessoa pede para exprimir as suas dúvidas, pois encontra Ricardo lendo "um romance policial, com uma botija aos pés, à espera duma criada que lhe venha aquecer o resto" e finaliza dizendo "quer que eu acredite que esse homem é aquele mesmo que escreveu Sereno e vendo a vida à distância a que está, é caso para perguntar-lhe onde é que estava quando viu a essa distância". Sem saber o que responder, Reis lembra o que Fernando disse "o poeta é um fingidor" 


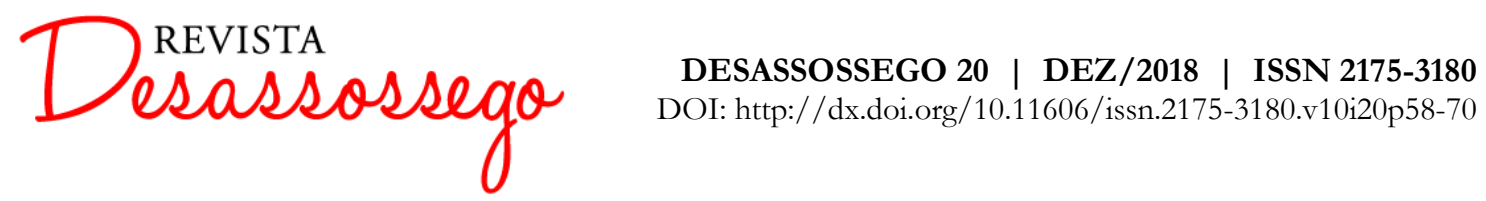

(SARAMAGO, 2000, p. 118), o primeiro verso do poema Autopsicografia. Pessoa mostra a Ricardo que a postura assumida por ele, enquanto artista, não pode ser, e não é, a mesma na vida real. Suas musas não existem, nem teriam como existir, pois são parte de um ideal clássico e neoclássico de arte, não condizente com a época presente.

Nesse diálogo, vemos um Fernando Pessoa, como anteriormente dito, irônico, debochado, morto, porém mais realista do que Ricardo Reis, que está vivo. Pessoa questionase, isto é, toma consciência de suas atitudes em vida, "o pior é que morri antes de ter percebido se é o poeta que se finge de homem ou o homem que se finge de poeta" (SARAMAGO, 2000, p. 118) e explica a diferença que há entre ele e Reis "eu apenas fingi, você finge-se" (SARAMAGO, 2000, p. 119). E conclui dizendo "o seu caso, Reis amigo, não tem remédio, você, simplesmente, finge-se, é fingimento de si mesmo" (SARAMAGO, 2000, p. 119). Reis defende-se o tempo todo, respondendo às perguntas, mas não toma consciência das palavras de Pessoa, mostrando-se, desse modo, alheio e indiferente às opiniões dele.

No sexto diálogo, Reis está esperando por Marcenda quando Pessoa o encontra e pergunta se ele está esperando por uma mulher. Após a resposta afirmativa de Reis, Pessoa diz:

Bravo, vejo que você se cansou de idealidades femininas incorpóreas, trocou a Lídia etérea por uma de encher as mãos, que eu bem a vi lá no hotel, e agora está aqui à espera doutra dama, feito D. João nessa sua idade, duas em tão pouco tempo, parabéns, para mil e três já não lhe falta tudo. (SARAMAGO, 2000, p. 182)

Reis fala que os mortos são piores que os velhos porque dizem tudo o que pensam. Pessoa responde-lhe que sempre faltou algo a ser dito. Reis pede que ele vá embora, pois Marcenda está chegando. Pessoa, ao vê-la, acha-a magra para o seu gosto. Reis diz que essa é a primeira vez que o ouve falar a respeito de mulheres. Pessoa despede-se de Reis dizendo: "deixo-o a namorar a pequena, você afinal desilude-me, amador de criadas, cortejador de donzelas, estimava-o mais quando você via a vida à distância a que está” (SARAMAGO, 2000, p. 183).

Pessoa cobra uma posição de Reis em relação às mulheres, pois ele está envolvido com duas, uma criada de hotel e uma moça de família. Entretanto, não está apaixonado por 


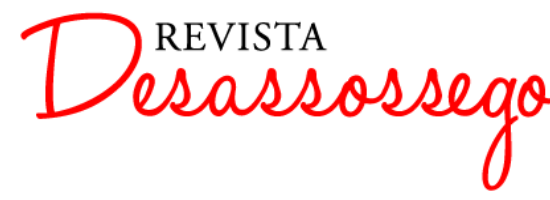

DESASSOSSEGO 20 | DEZ/2018 | ISSN 2175-3180

DOI: http://dx.doi.org/10.11606/issn.2175-3180.v10i20p58-70

nenhuma. Por esse motivo, há uma cobrança de uma atitude na vida semelhante a sua na arte. Isto quer dizer que o modo de Reis tratar as mulheres e as musas é diferente na vida e na arte.

No interrogatório da PVDE, Ricardo Reis mostra o quanto ele é alheio e desinteressado por política e todo o resto. "Sou médico, não sei nem quero saber de revoluções" ou "sou uma pessoa pacífica" (SARAMAGO, 2000, p. 192). Por um milagre sai ileso, mas ganha um novo amigo: Victor, o qual sempre reconhecerá pelo cheiro de cebola. Após o interrogatório, resolve sair do hotel e procurar uma nova morada. Lídia propõe-se a ajudá-lo. Mais tarde, ao reconhecer esse desinteresse pelo mundo, “Acaba por impor a si mesmo o dever de preocupar-se um pouco" (SARAMAGO, 2000, p. 192).

Além de tudo visto antes, ao longo da história pode-se perceber referências a romances que serão escritos depois por Saramago. Quem sabe não estaria aqui a gênese do Evangelho segundo Jesus Cristo:

Por isso é duvidoso ter-se despedido Cristo da vida com as palavras da escritura, as de Mateus e Marcos, Deus meu, Deus meu, por que me desamparaste, ou as de Lucas, Pai, nas tuas mãos entrego o meu espírito, ou as de João, Tudo está cumprido, o que Cristo disse foi, palavra de honra, qualquer pessoa popular sabe que é esta a verdade, Adeus, mundo, cada vez a pior (SARAMAGO, 2000, p. 60).

Ao subverter as palavras do Evangelho cristão e dar voz ao próprio Cristo, Saramago torna explícito o seu desprezo pela Igreja, pois além de ateu, ele não concorda com o dogma da Igreja Católica. Esta censurou o tratamento profano dado a Cristo em seu romance. Há, também, uma referência a $A$ jangada de pedra, numa conversa entre Ricardo Reis e Fernando Pessoa, esse diz: "Você anda a flutuar no meio do Atlântico, nem lá, nem cá" e Ricardo Reis responde: "Como todos os portugueses" (SARAMAGO, 2000, p. 361).

\section{Considerações finais}

A relação entre literatura e história, ao longo do romance, dá-se por meio dos intertextos, principalmente com Fernando Pessoa. A partir daí, Saramago faz com que Ricardo Reis reflita sobre o seu papel, o seu lugar, o porquê de seu regresso à pátria. Pessoa é, além de irônico e crítico, invejoso, pois, assim como não colocou Camões na Mensagem, não aceita a 


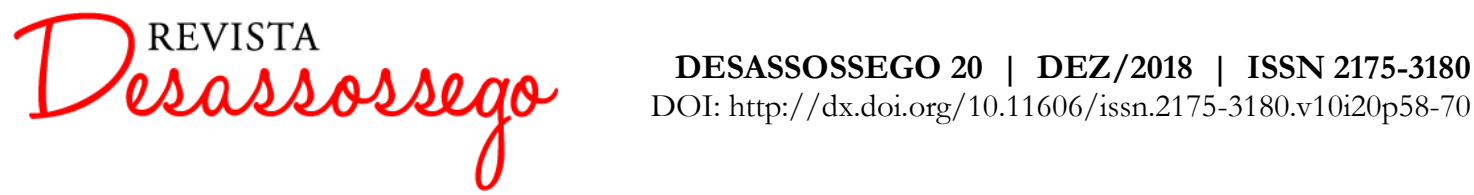

mudança de seu heterônimo, fazendo com que ele o acompanhe em sua última viagem. Reis não pode assumir o lugar de Fernando Pessoa porque não está preparado e porque não sabe quem ele realmente é. Isso o torna parte de Fernando Pessoa e sua única saída é acompanhar o seu criador.

No final, após reconhecer a sua mudança, de que não era mais aquele homem sábio que assistia ao espetáculo do mundo, mas que fazia parte desse espetáculo, Ricardo Reis resolve ir embora com Fernando Pessoa, levando o livro The god of the labyrinht e deixando "o mundo aliviado de um enigma" (SARAMAGO, 2000, p. 415). Ele não consegue mais ler, pois, como Fernando Pessoa tinha dito, a primeira coisa que se perde ao morrer é a leitura. Esse é o sinal de sua morte para o mundo.

\section{Referências}

BORGES, Jorge Luis. Obra Completa. São Paulo: Editora Globo, 2000. vol.1.

CARVALHAL, Tânia Franco. Literatura Comparada. São Paulo: Editora Ática, 1992.

LE GOFF, Jacques (org). A História Nova. São Paulo: Martins Fontes, 2001.

PESSOA, Fernando. Poesias de Ricardo Reis. São Paulo: Companhia das Letras, 2000.

PESSOA, Fernando. Páginas de doutrina estética. Lisboa: Inquérito, 1975.

RABELO, Luís de Sousa. "Resenha de O ano da morte de Ricardo Reis". In: Colóquio/Letras, (88): 144-148, novembro de 1985.

SARAIVA, José Hermano. História concisa de Portugal. Lisboa: Europa-América, 1985.

SARAMAGO, José. O ano da morte de Ricardo Reis. São Paulo: Companhia das Letras, 2000. 